\title{
Overstory-understory relations in pinyon-juniper woodlands in New Mexico
}

REX D. PIEPER

Abstract

Herbage blomass for blue grama (Bouteloua gracilis [H.B.K. Lag], pinyon ricegrass (Piptochaetium fimbriatum [H.B.K.] Hitchc.), New Mexjco muhly (Muhlenbergia pauciflora Buckl.), other grasses, and forbs was estimated on 25 piny on-juniper stands of varying overstory cover on the Fort Stanton Experimental Ranch in southcentral New Mexico. Negative $2^{\text {nd }}$ degree polynomial curves best expressed the relationships between total understory and blue grama biomass and overstory canopy cover. Positive polynomial relationships were shown for cool-season grasses, New Mexico muhly, and pinyon ricegrass. Reducing pinyon-juniper canopy cover would likely increase blue grama production and reduce production of New Mexico muhly and pinyon ricegrass.

Key Words: canopy cover, Pinus edulis, Juniperus monosperma, standing crop, herbage production

Pinyon-juniper woodlands represent important resources in the Southwest. Although they are used for many purposes (Everett 1988, Hurst 1975, Johnson 1975, Schreyer and Royer 1975, and Springfield 1976), livestock grazing remains one of the dominant uses. There is considerable evidence that density of pinyon and juniper trees has increased during the past 150 years in many of these woodlands (Johnsen 1962, Pieper 1977, Springfield 1976, West and Van Pelt 1987, and West et al. 1975). Increased tree density typically reduces forage available for grazing herbivores.

Canopy cover is one of the primary factors influencing understory vegetation in forest and woodland vegetation (Bartlett and Betters 1983). Basic relationships between canopy cover and understory biomass have been determined for pinyon-juniper woodlands in Arizona (Arnold et al. 1964, Clary 1971, Clary et al. 1974, Jameson 1967, Pieper 1983) and in western New Mexico (Short et al. 1977) and Nevada (Everett et al. 1985, Tausch and Tueller 1977). These relationships are curvilinear with polynomial or exponential equations describing the influence of canopy cover on understory production. Such studies have elucidated some of the basic ecological relationships among the species involved and have served as a guide to expected increase in herbaceous biomass following reductions of tree canopy.

Schott and Pieper (1985) described the influence of oneseed juniper (Juniperus monosperma [Engelm.]) canopy on basal cover of understory species, and Armentrout and Pieper (1988) described vegetational zonation patterns associated with individual trees of both oneseed juniper and Rocky Mountain pinyon (Pinus edulis [Engelm.]). However, little additional work has been done on overstory-understory relationships in pinyon-juniper stands in central New Mexico. Consequently, the objective of this study was to determine the relationship between overstory cover and herbaceous biomass.

\section{Materials and Methods}

The study was conducted on the Fort Stanton Experimental

\footnotetext{
Author is professor of range science, New Mexico State University, Las Cruces 88003.

Journal Article 1476 of the New Mexico Agr. Exp. Sta., Las Cruces.
}

Ranch in the foothills of the Sacramento Mountains of southcentral New Mexico, about $6.5 \mathrm{~km}$ east of Capitan, N.Mex. The area is characterized by cool, dry winters, and warm, moist summers with cool nights (Pieper et al. 1971). Long-term annual precipitation is about $348 \mathrm{~mm}$ (Rippel et al 1983), of which about 65\% occurs between July and September. Average annual precipitation for 7 rain gauges on the study area was $451 \mathrm{~mm}$ in 1984 and $390 \mathrm{~mm}$ in 1985.

The vegetational mosaic of the area is represented by pinyonjuniper woodland on the slopes and areas of rough terrain and grassland on the undulating mesa tops. Dominant overstory trees are oneseed juniper, Rocky Mountain pinyon, and scattered alligator juniper (Juniperus deppeana [Steud.]). The understory is represented by several species of grasses and forbs (Lebgue and Allred 1985).

Areas supporting pinyon-juniper woodlands with no or light grazing by cattle shown on aerial photographs were overlain by a dot grid, and 25 locations were selected at random from this grid. Each area was located in the field as accurately as possible. At each location, a $15 \times 25-\mathrm{m}$ macro plot was established and the long and short diameter of each tree in the plot was measured. Canopy cover was calculated using the formula for a circle, since the shape of canopy of these trees was more circular than elliptical. Three transects were randomly located across the length of the plot, and all rooted plants within five $2 \times 5 \mathrm{dm}$ plots per transect were clipped, separated into blue grama (Bouteloua gracilis [H.B.K.] Lag.), pinyon ricegrass (Piptochaetium fimbriatum [H.B.K.] Hitchc.), New Mexico muhly (Muhlenbergia pauciflora Buckl.), other grass, and forbs, and weighed. All field sampling was completed in late August and early September. Quadrat locations were randomized each year to avoid sampling the same spot the second year.

Simple linear, logarithmic, exponential, and quadratic regression analyses were conducted using Stat View 512+ software on a MacIntosh II computer. Total tree canopy cover was considered the independent variable, and total, blue grama, pinyon ricegrass, New Mexico muhly, other grass, and forb biomass were the dependent variables. The best fit curves were selected based on high coefficients of determination, low standard errors, and level of significance of the model. Plots of the residuals were used to evaluate the curves selected.

Tree overstory was determined only in 1984; understory biomass was determined both in 1984 and 1985. Biomass data collected in 1984 were used to develop the basic regression equations, and 1985 data were used to validate the models since precipitation patterns were similar for both years. Validation was accomplished by simple linear regression analysis of actual versus predicted values developed from the equations.

\section{Results and Discussion}

\section{Overstory-Understory Relations}

A $2^{\text {nd }}$ degree polynomial best described the relationship between pinyon-juniper canopy and total biomass and blue grama biomass. Tree canopy cover and total herbaceous understory biomass was 


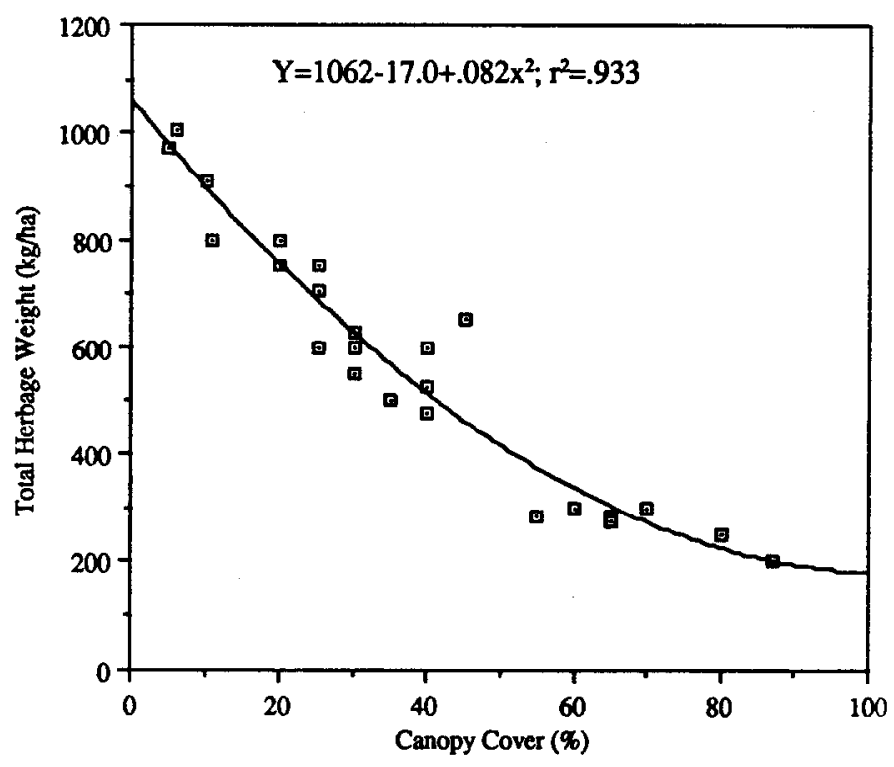

Fig. 1. Relationship between canopy cover and total herbage biomass.

highly significantly inversely related $\left(P>0.0001, r^{2}=0.93\right)$. Reductions in canopy cover between 85 and $60 \%$ resulted in relatively small increases in understory biomass (Fig. 1). The curve is much steeper in understory biomass response between 0 and $40 \%$ canopy cover. Blue grama biomass was also highly negatively related to canopy cover $\left(P<0.0001, r^{2}=0.91\right)$ (Fig. 2). These curves were flatter than those reported for sites in Arizona (Clary et al. 1974, Jameson 1967) and western New Mexico (Short et al. 1977), but the shapes were similar. Apparently, reducing the canopy at high levels was more effective in increasing both total and blue grama herbage weight in central New Mexico than in areas farther west. Differences in both overstory and understory species may account for these slightly different curves. Reduced light intensity at higher canopy levels, competitive interactions for water and nutrients, and litter accumulation (Harper 1977, Walker et al. 1986) are likely factors responsible for the reduction in understory biomass, although measurement of light intensities and other interactions have not been made (Armentrout and Pieper 1988). Similar

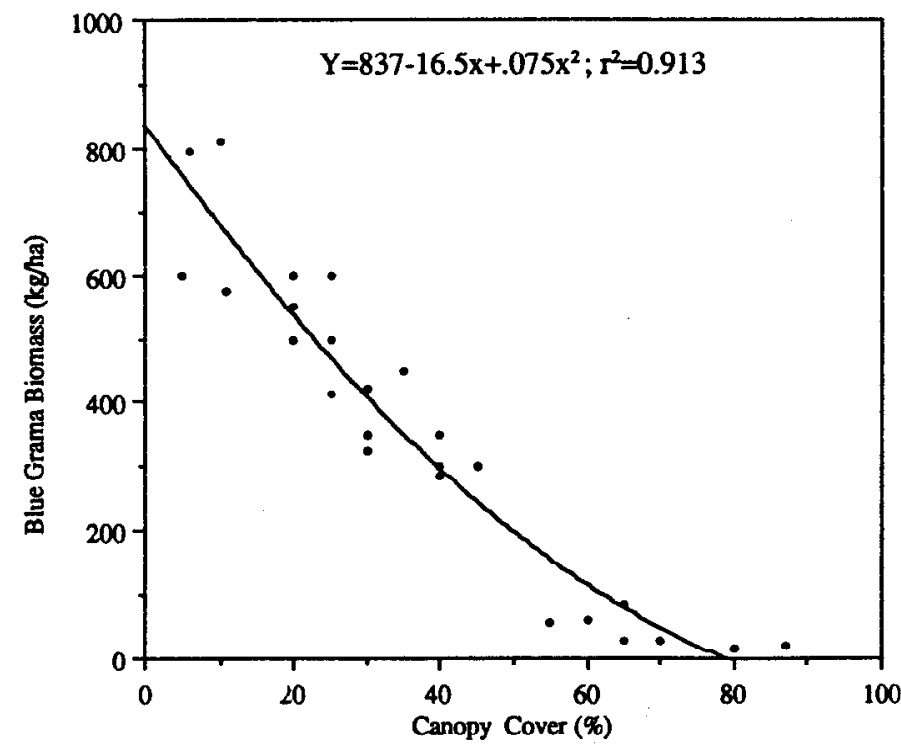

Fig. 2. Relationship between canoy cover and blue grama biomass.

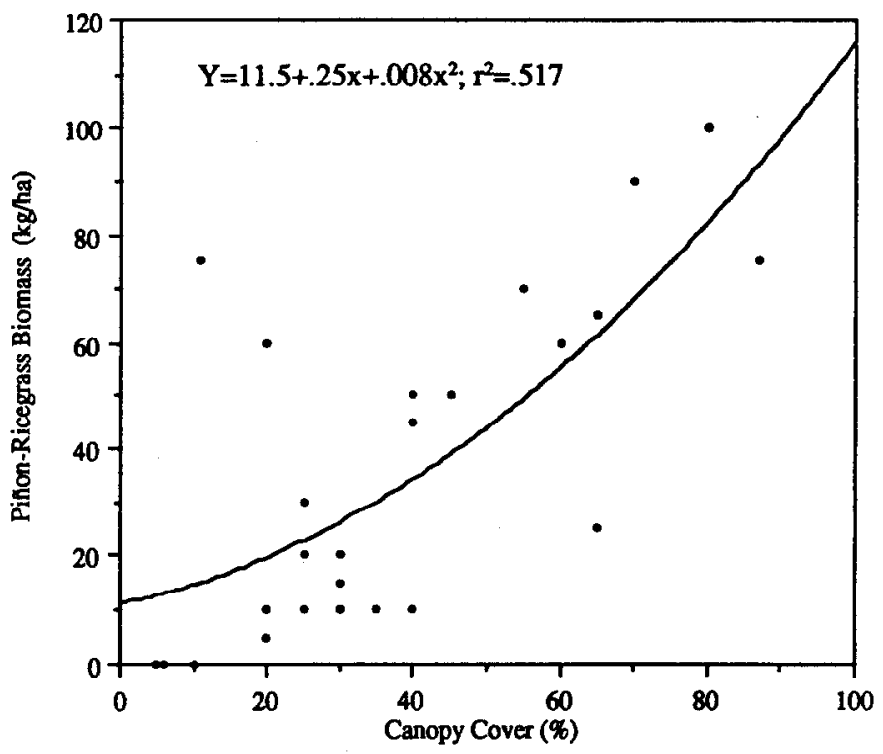

Fig. 3. Relationship between canopy cover and pinyon-ricegrass biomass.

responses have been revealed for other woodlands and forests in western U.S. (Bartlett and Betters 1983).

Reductions of blue grama biomass from open stands to dense stands agrees with data reported by Armentrout and Pieper (1988) and Schott and Pieper (1987). Schott and Pieper (1987) found blue grama cover was much higher near the edge of oneseed juniper canopy than near the center of the canopy. Apparently, blue grama is relatively intolerant of shade or other competitive interactions.

Biomass of 2 cool-season grass species-pinyon ricegrass and New Mexico muhly - was positively related to tree canopy cover (Figs. 3 and 4). However, biomass of these 2 species was much less than that for blue grama. The data for these species exhibited higher variability than that for blue grama $\left(r^{2}=0.52\right.$ for pinyon ricegrass and $r^{2}=0.64$ for New Mexico muhly). Apparently, these cool-season grass species have relatively high tolerance for low light intensities and other changes in environmental conditions associated with increases in pinyon-juniper cover. These data agree

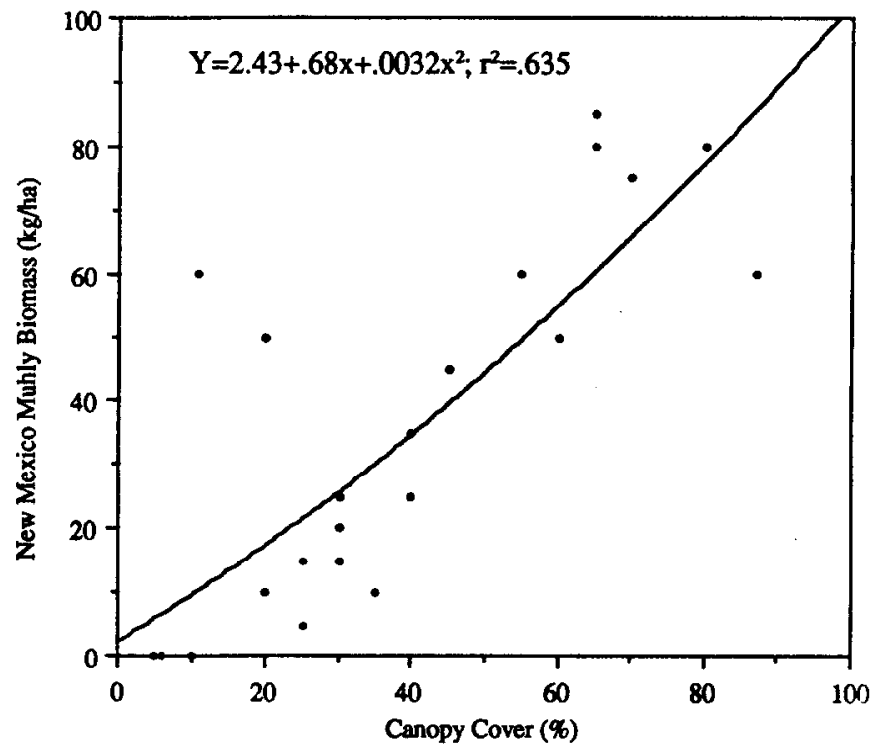

Fig. 4. Relationship between canopy cover and New Mexico muhly biomass. 
with those of Clary and Morrison (1973), who found that alligator juniper benefited cool-season grasses in Arizona. The direct relationship between biomass of New Mexico muhly and pinyon ricegrass and overstory cover helps explain the better relationship between overstory cover and blue grama biomass than that for total biomass, which includes both cool and warm season grass species.

Biomass of other grass and forb species was not strongly related to overstory canopy cover. A simple linear regression showed that overstory canopy cover explained only $16.5 \%$ of the variation of other grass biomass and about $14 \%$ of the variation in forb biomass. Obviously, these groups include species that are reacting differently to the tree canopy.

Blue grama biomass was negatively related to both New Mexico muhly and pinyon ricegrass biomass. A $2^{\text {nd }}$ degree polynomial appeared to describe these relationships best. Such a relationship is to be expected because these species reacted in an opposite manner to tree overstory. On the other hand, biomass of New Mexico muhly and pinyon ricegrass showed a positive linear relationship. Each percent increase of $1 \mathrm{~kg} / \mathrm{ha}$ biomass of pinyon ricegrass corresponded to an increase of $0.68 \mathrm{~kg} / \mathrm{ha}$ biomass of New Mexico muhly. Additional research is needed to gain a better understanding of the competitive relationships among these understory species.

\section{Validation}

The highest $r^{2}$ value for the relationship between actual vs. predicted biomass values was that for blue grama $\left(r^{2}=0.91\right.$, Fig. 5), followed by total biomass $\left(r^{2}=0.76\right)$, New Mexico muhly $\left(r^{2}=0.26\right)$ and pinyon ricegrass $\left(r^{2}=0.24\right)$. Apparently, blue grama is sensitive to tree canopy overstory, and the relationship is fairly stable from year to year when precipitation is comparable.

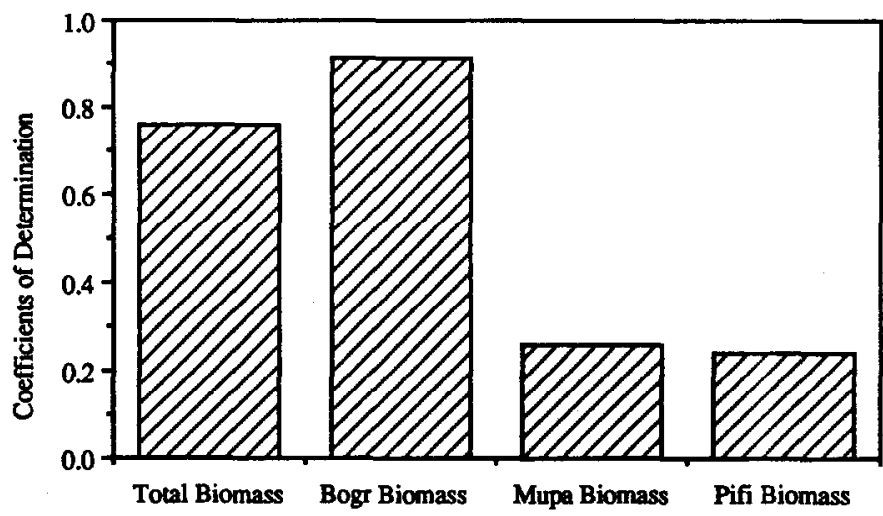

Fig. 5. Coefincients of determination for actual vs. predicted biomass for various vegetational components. Bogr $=$ Bouteloua gracilis, Mupa = Muhlenbergia pauciflora, Pif = Piptochaetum fimbriatum.

\section{Management Implications}

These data suggest that decreasing overstory canopy of pinyonjuniper woodlands in central New Mexico will tend to increase blue grama biomass, but decrease biomass of cool-season grasses such as New Mexico muhly and pinyon ricegrass. If the latter species are important as a grazing resource, some mosaic pattern of tree control may benefit grazing values as well as aesthetic values (Williamson and Currier 1971).

These data provide some indication of herbage production potentials under different levels of canopy cover of pinyon-juniper trees. Increases in herbage production are relatively small unless canopy cover can be reduced substantially. These data can be used in planning modifications of pinyon-juniper woodlands.

\section{Literature Cited}

Amold, J.F., D.A. Jameson, and E.H. Reid. 1964. The pinyon-juniper type of Arizona: Effects of grazing, fire, and tree control. USDA Prod. Res. Rep. 84.

Armentrout, S.M., and R.D. Pieper. 1988. Plant distribution surrounding Rocky Mountain pinyon pine and oneseed juniper in south-central New Mexico. J. Range Manage. 41:139-143.

Bailey, O.F., L.A. Daugherty, and G.B. Donart. 1982. Soil survey of the Fort Stanton Experimental Ranch-Phase I. New Mexico State Univ. Agr. Exp. Sta. Spec. Rep. 43.

Bartlett, E.T., and D.R. Betters (Eds.). 1983. Overstory-understory relationships in western forests. West. Reg. Res. Pub. 1. Colorado State Univ. Agr. Exp. Sta., Ft. Collins.

Clary, W.P. 1971. Effects of Utah juniper removal on herbage yields from Springerville soils. J. Range Manage. 24:373-378.

Clary, W.P., M.B. Baker, Jr., P.E. O'Connell, T.N. Johnsen, Jr., and R.E. Campbell. 1974. Effects of pinyon-juniper removal on natural resource product and uses in Arizona. USDA Forest Serv. Res. Pap. RM-128.

Clary, W.P., and D.C. Morrison. 1973. Large alligator junipers benefit early-spring forage. J. Range Manage. 26:70-71.

Everett, R.L., and S.H. Sharrow. 1985. Response of grass species to tree harvesting in singleleaf pinyon-utah juniper stands. USDA Forest Serv. Res. Pap.INT-334.

Everett, R.L. (Compiler). 1987. Proc. Pinyon-juniper conf. USDA Forest Serv. Gen. Tech. Rep. INT-215.

Harper, J.L. 1977. Population biology of plants. Academic Press. London.

Hurst, W.D. 1975. Management strategies within the pinyon-juniper ecosystem. In: The pinyon-juniper ecosystem: A symposium. Utah State Univ. Agr. Exp. Sta., Logan.

Jameson, D.A. 1967. The relationship of tree overstory and herbaceous understory vegetation. J. Range Manage. 20:247-249.

Johnsen, T.N, 1962. One-seed juniper invasion of northern Arizona grasslands. Ecol. Monog. 32:187-207.

Johnson, C.M. 1975. Pinyon-juniper forests: asset or liability. In: Gifford, G.F. and F.E. Busby (Eds.). The pinyon-juniper ecosystem: A symposium. Utah State Univ. Agr. Exp. Sta., Logan.

Lebgue, T., and K.W. Allred. 1985. Flora of the Fort Stanton Experimental Ranch, Lincoln County, New Mexico. New Mexico State Univ. Agr. Exp. Sta. Res. Rep. 557.

Pieper, R.D.1977. The southwestern pinyon-juniper ecosystem. In: Aldon, E.F. and T.J. Loring (Tech. Coords.). Ecology, uses and management of pinyon-juniper woodlands. USDA Forest Gen. Tech. Rep. RM-39.

Pieper, R.D. 1983. Overstory-understory relationships: pinyon-juniper woodlands. In: Bartlett, E.T. and D.R. Betters (Eds.). Overstoryunderstory relationships in western forests. West. Reg. Res. Pub. 1. Colorado State Univ. Agr. Exp. Sta., Ft. Collins.

Pieper, R.D., J.R. Montoya, and V.L. Groce. 1971. Site characteristics on pinyon-juniper and blue grama ranges of south-central New Mexico. New Mexico State Univ. Agr. Exp. Sta. Bull. 573.

Rippel, P., R.D. Pieper, and G.A. Lymbery. 1983. Vegetational evaluation of pinyon-juniper cabling in south-central New Mexico. J. Range Manage. 36:13-15.

Schott, M.R., and R.D. Pieper. 1985. Influence of canopy characteristics of one-seed juniper on understory grasses. J. Range Manage. 38:328-331.

Schreyer, R., and L.E. Royer. 1975. Impacts of pinyon-juniper manipulation on recreation and aesthetics. In: The pinyon-juniper ecosystem: A symposium. Utah State Univ. Agr. Exp. Sta., Logan.

Short, H.L., W. Evans, and E.L. Boeker. 1977. The use of natural and modified pinyon-juniper woodlands by deer and elk. J. Wildl. Manage. 41:543-559.

Springfield, H.W. 1976. Characteristics and management of southwestern pinyon-juniper ranges: the status of our knowledge. USDA Forest Serv. Res. Pap. RM-160.

Tausch, R.J., and P.T. Tueller. 1977. Plant succession following chaining of pinyon-juniper woodlands in eastern Nevada. J. Range Manage. 30:40-44.

West, N.E., K.H. Rea, and R.J. Tausch. 1975. Basic synecological relationships in juniper-pinyon woodlands. In: The pinyon-juniper ecosystem: a symposium. Utah State Univ. Agr. Exp. Sta., Logan.

West, N.E., and N.S. Van Pelt. 1987. Successional patterns in pinyonjuniper woodlands. In: Everett, R.L. (Compiler). Proc. Pinyon-juniper conference. USDA For. Ser. Gen. Tech. Rep. Int. 215.

Williamson, R.M., and W.F. Currier. 1971. Applied landscape management in plant control. J. Range Manage. 24:2-6. 